\title{
Selectivity of Saflufenacil Applied Alone or Mixed to Glyphosate in Maize
}

\author{
Leandro Galon (Corresponding author) \\ Laboratory of Sustainable Management of Agricultural Systems, Federal University of \\ Fronteira Sul, Erechim Campus \\ RS 135 - km 72, n. 200, 99.700-000, Erechim, RS, Brazil \\ E-mail: leandro.galon@uffs.edu.br \\ Tel.: $+55-5433217347$
}

\begin{abstract}
Sabrina Natalia Weirich
Laboratory of Sustainable Management of Agricultural Systems, Federal University of Fronteira Sul, Erechim Campus

RS 135 - km 72, n. 200, 99.700-000, Erechim, RS, Brazil

E-mail: weirichsabrina@hotmail.com
\end{abstract}

Milena Barretta Franceschetti

Laboratory of Sustainable Management of Agricultural Systems, Federal University of Fronteira Sul, Erechim Campus

RS 135 - km 72, n. 200, 99.700-000, Erechim, RS, Brazil

E-mail: milena.barretta@hotmail.com

Ignacio Aspiazú

Department of Agricultural Sciences, State University of Montes Claros

Av. Reinaldo Viana, n.2630, Pico da Pedra, 39440-000, Janaúba/MG, Brazil

E-mail: ignacio.aspiazu@unimontes.br

Alexandre Ferreira da Silva

Research Scientist at Embrapa Milho e Sorgo, Rodovia MG 424, km 45, Zona Rural, 
35701-970, Sete Lagoas, MG, Brazil

E-mail: alexandre.ferreira@embrapa.br

\author{
Cesar Tiago Forte \\ Department of Agronomy, Federal University of Santa Maria \\ Av. Roraima, n. 1000, 97.105-900, Santa Maria, RS, Brazil \\ E-mail: cesartiagoforte@hotmail.com
}

\begin{abstract}
Emanuel Rodrigo de Oliveira Rossetto
Laboratory of Sustainable Management of Agricultural Systems, Federal University of Fronteira Sul, Erechim Campus

RS 135 - km 72, n. 200, 99.700-000, Erechim, RS, Brazil

E-mail: emanuelrossetto2011@gmail.com
\end{abstract}

\title{
Daiani Brandler
}

Laboratory of Sustainable Management of Agricultural Systems, Federal University of Fronteira Sul, Erechim Campus

RS 135 - km 72, n. 200, 99.700-000, Erechim, RS, Brazil

E-mail: daianibrandler@hotmail.com

\section{Gismael Francisco Perin}

Laboratory of Sustainable Management of Agricultural Systems, Federal University of Fronteira Sul, Erechim Campus

RS 135 - km 72, n. 200, 99.700-000, Erechim, RS, Brazil

E-mail: gismaelperin@gmail.com

\section{Cleiton Ulkovski}

Laboratory of Sustainable Management of Agricultural Systems, Federal University of Fronteira Sul, Erechim Campus

RS 135 - km 72, n. 200, 99.700-000, Erechim, RS, Brazil 
E-mail: cleiton-ulk@hotmail.com

Received: May 4, 2020

doi:10.5296/jas.v8i3.16957
Accepted: May 27, 2020 Published: June 1, 2020

URL: https://doi.org/10.5296/jas.v8i3.16957

\begin{abstract}
The use of selective herbicides is important for weed management in agricultural crops. Selectivity studies of new molecules are really important to expand the control options of glyphosate-resistant and -tolerant eudicotyledons in corn. The objective of this work was to evaluate the selectivity of the herbicide saflufenacil applied alone in different doses in post-emergence of corn and in a mixture with glyphosate. The design used was randomized blocks, with four replications, with treatments consisting of five doses of saflufenacil, applied alone and in a mixture with a fixed dose of glyphosate, in addition to the weeded control and only glyphosate. At 7, 14, 21 and 28 days after application (DAT), the phytotoxicity of the herbicides to the crop was evaluated. The physiological variables were measured at 35 DAT. At harvest, yield components were determined, in addition to the mass of 1,000 grains and grain yield. The application of the mixture of glyphosate with saflufenacil increases phytotoxicity symptoms and yield losses. Doses of up to $70 \mathrm{~g} \mathrm{ha}^{-1}$, applied alone, caused low phytotoxicity to corn and did not interfere in yield. The use of glyphosate + saflufenacil tank mixtures caused decreases in yield of 43.96 and $40.81 \%$ when compared, respectively, with the weeded control and the averages of the applications of the herbicides alone. Saflufenacil has the potential to be used in the management of eudicotyledonous weeds, as long as it is not mixed with glyphosate and the dose limit is respected.
\end{abstract}

Keywords: phytotoxicity, tank mix, Zea mays L, yield

\title{
1. Introduction
}

Brazil stands out as the third largest worldwide producer of corn, with an estimated area of 17.89 million hectares, production of 100.08 million tons and average yield of $5.5 \mathrm{tha}^{-1}$ (CONAB, 2020). Increasing grain yield is one of the main challenges for corn producers. Yield increases can be obtained through good agricultural practices, among which weed management stands out as one of the main items. The lack of control of the weed community can cause losses of income above $80 \%$ (Basso et al., 2018).

For the management of corn weeds, chemical control is the most used method due to its ease, effectiveness and low cost when compared to other alternatives (Timossi and Freitas 2011; Galon et al., 2018). The introduction of glyphosate-resistant (GR) corn hybrids caused a major change in the management strategies of the weed community. Due to its low cost, broad spectrum of action, efficacy and selectivity, this herbicide has become the main molecule used for weed control in GR crops (Silva et al., 2017). However, its continuous use has been causing an increase in selection pressure, favoring the occurrence of resistant 
biotypes and species that are tolerant to this active ingredient. (Lucio et al., 2019). Associated with this scenario, crops in succession of GR crops have also been causing an increase in the frequency of volunteer plants, resulting from the loss of grains from the previous crop, which compete with the crop of economic interest for the resources of the environment (Petter et al., 2015).

Controlling volunteer soybeans in corn is an important practice, considering that in Brazil around $69 \%$ of it is produced in the off-season (Contini et al., 2019), which, most of the time, is sown after the cultivation of GR soybeans. In view of this scenario, the association of glyphosate with herbicides with different mechanisms of action is an important practice for proper weed management in GR corn. Atrazine is characterized as the main molecule used in association with glyphosate. This herbicide proves to be efficient in the control of volunteer soybeans and can assist in the management of some species that are tolerant and some biotypes that are resistant to glyphosate (Costa et al., 2019). However, it is important to look for alternatives to the use of atrazine, because, due to its high leaching potential, it has caused contamination of groundwater, in addition to being banned in some European countries (Lourencetti et al., 2005).

Saflufenacil is a broadleaf herbicide widely used for desiccation, showing excellent performance on weeds that are difficult to control with glyphosate, being also recommended for controlling volunteer soybeans (MAPA/AGROFIT, 2020). It acts by contact, inhibiting the enzyme protoporphyrinogen oxidase, also called PPO or PROTOX (Grossman et al., 2010). The absorption of this herbicide occurs through leaves or roots, with translocation via xylem. Visual symptoms in sensitive plants are dark green patches on the leaves, following a necrosis until the leaves dry (Rodrigues and Almeida, 2018). This herbicide is registered for use in pre-sowing desiccation of corn (MAPA/AGROFIT, 2020). Thus, studies that evaluate the selectivity of saflufenacil applied alone or in combination with glyphosate in the post-emergence of corn are very important to know the viability of using this herbicide in the crop and, in particular, for the control of genetically modified volunteer soybean plants, resistant to glyphosate and, or, ammonium-glufosinate.

The objective of this work was to evaluate the selectivity of saflufenacil, applied in different doses, alone or in association with glyphosate, in corn plants.

\section{Material and Methods}

The experiment was carried out under field conditions, in the experimental area of the Federal University of Fronteira Sul (UFFS), campus Erechim/RS, in the 2018/19 crop season. The region's soil is classified as a typic alumino-ferric Red Latossol (Rhodic Hapludox) (EMBRAPA, 2013). Sowing was carried out under no-tillage system. The correction of soil fertility was carried out based on the results of its chemical analysis and following the fertilization recommendations for corn (ROLAS, 2016).

The trial was installed in a randomized block design with twelve treatments and four replications. Each experimental unit had dimensions of $5 \times 3 \mathrm{~m}$, totaling an area of $15 \mathrm{~m}^{2}$, 
containing six seeding rows spaced $0.5 \mathrm{~m}$ apart. The evaluated area of the plots corresponded to the four central lines, discarding the borders.

The trial was sown on 11/20/2018, using the super-early simple hybrid SYN 488 VIP 3 . The average seed density per meter was 3.64 with a population of approximately 72,800 plants $\mathrm{ha}^{-1}$. For base fertilization, $433 \mathrm{~kg} \mathrm{ha}^{-1}$ of the formula 02-20-20 of NPK were used, with an additional $139 \mathrm{~kg} \mathrm{ha}^{-1}$ of $\mathrm{N}$ topdressing, in the form of urea, when the corn had four fully expanded leaves (V4 stage).

The herbicides were applied when the corn plants had between four (V4) to five (V5) completely expanded leaves. A precision backpack sprayer pressurized with $\mathrm{CO}_{2}$ was used, equipped with four DG 110.02 fan spray tips, under constant pressure of $210 \mathrm{kPa}$ and displacement speed of $3.6 \mathrm{~km} \mathrm{~h}^{-1}$, which resulted in a flow of $150 \mathrm{~L} \mathrm{ha}^{-1}$ of herbicide spray. The environmental conditions at the time of application (12/20/2018) were favorable, with clear skies, no clouds, wind speed of $2.5 \mathrm{~km} \mathrm{~h}^{-1}$, air temperature of $25^{\circ} \mathrm{C}$ and soil temperature of $29.8^{\circ} \mathrm{C}$, with a relative humidity of $58 \%$. The treatments are shown in Table 1.

The herbicides used were saflufenacil and glyphosate, applied alone or in mixtures. For the control of weeds that infested corn during the experiment, the herbicide ammonium-glufosinate was used at a dose of $400 \mathrm{~g} \mathrm{ha}^{-1}$ plus the adjuvant recommended by the manufacturer.

The evaluations of phytotoxicity to the corn crop occurred at 7, 14, 21 and 28 days after the application of the treatments (DAT). For that, percentage scores were assigned, ranging from zero to 100 , where $0 \%$ corresponds to the absence of symptoms and $100 \%$ to the death of plants (SBCPD, 1995).

Table 1. Treatments used in the experiment, respective doses and adjuvant, in order to verify the selectivity of the SYN 488 VIP 3 corn hybrid. UFFS/Erechim/RS, 2018/19

\begin{tabular}{lcccc}
\hline Treatments & $\begin{array}{c}\text { Doses a.i. } \\
\left(\mathrm{g} \mathrm{ha}^{-1}\right)\end{array}$ & $\begin{array}{c}\text { Doses } \\
\left(\mathrm{L} \mathrm{kg}^{-1} \mathrm{ha}^{-1}\right)\end{array}$ & $\begin{array}{c}\text { Adjuvant } \\
(\% \mathrm{v} / \mathrm{v})\end{array}$ \\
\hline T01- Weeded control (hoeing) & $\ldots$ & $\ldots$ & $\ldots$ & $\ldots$ \\
T02- Glyphosate & 1,335 & 3.000 & $\ldots$ & $\ldots$ \\
T03- Saflufenacil & 35 & 0.050 & Assist & 0.50 \\
T04- Saflufenacil & 52,5 & 0.075 & Assist & 0.50 \\
T05- Saflufenacil & 70 & 0.100 & Assist & 0.50 \\
T06- Saflufenacil & 87.5 & 0.125 & Assist & 0.50 \\
T07- Saflufenacil & 105 & 0.150 & Assist & 0.50 \\
T08- Saflufenacil + glyphosate & $35+1,335$ & $0.050+3.000$ & Assist & 0.50 \\
T09- Saflufenacil + glyphosate & $52.5+1,335$ & $0.075+3.000$ & Assist & 0.50 \\
T10- Saflufenacil + glyphosate & $70+1,335$ & $0.100+3.000$ & Assist & 0.50 \\
T11- Saflufenacil + glyphosate & $87.5+1335$ & $0.125+3.000$ & Assist & 0.50 \\
T12- Saflufenacil + glyphosate & $105+1335$ & $0.150+3.000$ & Assist & 0.50 \\
\hline
\end{tabular}


At 35 DAT, variables related to the physiology of corn plants were evaluated, such as: photosynthetic activity $\left(\mathrm{A}-\mu \mathrm{mol} \mathrm{m} \mathrm{m}^{-2} \mathrm{~s}^{-1}\right)$, leaf transpiration $\left(\mathrm{E}-\mathrm{mol} \mathrm{H}_{2} \mathrm{O} \mathrm{m} \mathrm{m}^{-2} \mathrm{~s}^{-1}\right)$, internal $\mathrm{CO}_{2}$ concentration $\left(\mathrm{Ci}-\mu \mathrm{mol} \mathrm{mol}^{-1}\right.$ ), stomatal conductance ( $\mathrm{Gs}-\mathrm{mol} \mathrm{m}^{-1} \mathrm{~s}^{-1}$ ), efficient water use (EWU - mol $\mathrm{CO}_{2} \mathrm{~mol} \mathrm{H}_{2} \mathrm{O}^{-1}$ ) and carboxylation efficiency ( $\mathrm{CE}-\mathrm{mol} \mathrm{CO}_{2} \mathrm{~m}^{-2} \mathrm{~s}^{-1}$ ), measured in the middle third of two corn plants in each experimental unit, in fully expanded leaves. To determine the physiological variables, an infrared gas analyzer (IRGA) (LCA PRO, Analytical Development Co. Ltd, Hoddesdon, UK) was used; each block was evaluated under natural light on one day, between eight and ten o'clock in the morning, under clear skies, so that the homogeneous environmental conditions were maintained during the analysis.

The variables evaluated before harvesting the corn were ear length (EL), number of rows per ear (NRE), number of grains per row (NGR) and number of grains per ear (NGE). For these evaluations, five ears of each experimental unit were randomly collected. The EL was measured with the aid of a ruler graduated in millimeters (mm). NRE, NGR and NGE were determined by manual counting. After harvesting the evaluated area $\left(6 \mathrm{~m}^{2}-2 \times 3 \mathrm{~m}\right)$, the mass of 1,000 grains was determined using an analytical scale, counting eight samples of 100 grains from each treatment, and later the yield was estimated for $\mathrm{kg} \mathrm{ha}^{-1}$. For these analysis, grain moisture was adjusted to $13 \%$.

The data obtained from the test were subjected to analysis of variance by the F test; when significant, means were compared using the Scott-Knott test $(\mathrm{p} \leq 0,05)$. All statistical analysis and graphics were performed using the software Sisvar (Ferreira, 2011).

\section{Results and Discussion}

The application of glyphosate alone was the only treatment that did not cause corn phytotoxicity in all evaluations (Table 2). The increase in injuries to corn is directly related to the increase in saflufenacil doses.

Table 2. Phytotoxicity (\%) to the SYN 488 VIP 3 corn hybrid due to the application of different doses of saflufenacil in isolation or in mixture with glyphosate. UFFS/Erechim/RS, 2018/19

\begin{tabular}{lcccc}
\hline \multirow{2}{*}{ Treatments } & \multicolumn{4}{c}{ Phytotoxicity to corn (\%) } \\
\cline { 2 - 5 } & $7 \mathrm{DAT}^{\mathrm{1}}$ & $14 \mathrm{DAT}$ & $21 \mathrm{DAT}$ & $28 \mathrm{DAT}$ \\
\hline T01-Weeded control (hoeing) & $0.00 \mathrm{~h}^{2}$ & $0.00 \mathrm{e}$ & $0.00 \mathrm{e}$ & $0.00 \mathrm{~g}$ \\
T02-Glyphosate & $0.00 \mathrm{~h}$ & $0.00 \mathrm{e}$ & $0.00 \mathrm{e}$ & $0.00 \mathrm{~g}$ \\
T03-Saflufenacil & $12.50 \mathrm{~g}$ & $5.00 \mathrm{e}$ & $10.00 \mathrm{~d}$ & $3.00 \mathrm{f}$ \\
T04-Saflufenacil & $27.25 \mathrm{f}$ & $12.25 \mathrm{~d}$ & $15.00 \mathrm{c}$ & $4.75 \mathrm{f}$ \\
T05-Saflufenacil & $27.25 \mathrm{f}$ & $26.50 \mathrm{c}$ & $17.50 \mathrm{c}$ & $6.75 \mathrm{f}$ \\
T06-Saflufenacil & $40.00 \mathrm{e}$ & $11.75 \mathrm{~d}$ & $20.00 \mathrm{c}$ & $18.25 \mathrm{e}$ \\
T07-Saflufenacil & $38.25 \mathrm{e}$ & $28.25 \mathrm{c}$ & $21.75 \mathrm{c}$ & $20.00 \mathrm{e}$ \\
T08-Saflufenacil + glyphosate & $50.00 \mathrm{~d}$ & $26.75 \mathrm{c}$ & $20.00 \mathrm{c}$ & $25.00 \mathrm{~d}$ \\
T09-Saflufenacil +glyphosate & $82.25 \mathrm{~b}$ & $66.75 \mathrm{~b}$ & $40.00 \mathrm{~b}$ & $37.25 \mathrm{c}$ \\
T10-Saflufenacil + glyphosate & $75.00 \mathrm{c}$ & $76.75 \mathrm{a}$ & $70.00 \mathrm{a}$ & $47.75 \mathrm{~b}$ \\
T11-Saflufenacil + glyphosate & $90.00 \mathrm{a}$ & $80.00 \mathrm{a}$ & $70.00 \mathrm{a}$ & $47.50 \mathrm{~b}$ \\
T12-Saflufenacil + glyphosate & $92.50 \mathrm{a}$ & $85.00 \mathrm{a}$ & $72.50 \mathrm{a}$ & $55.00 \mathrm{a}$ \\
\hline C.V. $(\%)$ & 9.45 & 14.51 & 18.01 & 11.98 \\
\hline
\end{tabular}


${ }^{1}$ Days after treatment application. ${ }^{2}$ Means followed by the same letter in the column do not differ by the Scott-Knott test at $p \leq 0,05$.

The symptoms observed were characterized by browning of corn leaves. In general, phytotoxicity levels decreased during the evaluation period. The rapid onset of symptoms is related to the mechanism of action of the herbicide. It is an active ingredient that has contact action and acts by inhibiting the PROTOX enzyme. This inhibition causes the appearance of reactive oxygen species, which promote the peroxidation of membrane lipids and, consequently, cell death (Grossmann et al., 2010). The mixture of glyphosate with saflufenacil aggravated the symptoms of phytotoxicity in corn. When comparing the levels of phytotoxicity caused by saflufenacil applied alone and in a mixture with glyphosate at 28 DAT, up to $41 \%$ more injuries were observed. The highest dose of saflufenacil caused milder symptoms than the lowest when applied in combination with glyphosate.

The aggravation of phytotoxicity symptoms caused by saflufenacil when applied in combination with glyphosate may be related to its higher absorption. Ashigh and Hall (2010), evaluating the interaction between these two molecules applied in mixture, observed that there is an increase in the absorption of these two herbicides and less translocation of glyphosate.

The higher internal concentration of saflufenacil directly interferes with corn tolerance, since the selectivity of this herbicide is mainly related to the metabolization of the product (Rodrigues and Almeida, 2018). The synergistic effect of the mixture of glyphosate and saflufenacil has been demonstrated in some studies, mainly in the control of dicots (Dalazen et al., 2015). Piasecki et al. (2017), evaluating different treatments in mixture for the control of hairy fleabane, observed that the combination of glyphosate + saflufenacil shows the best response of technical efficiency, that is, synergism occurs when associating the two products.

Analyzing the physiological parameters, it was observed that there was no relationship between the levels of phytotoxicity (Table 2) and the analyzed variables (Table 3). Stomatal conductance (Gs) showed little influence by the use of herbicides; only the highest dose of saflufenacil mixed with glyphosate increased this variable. The higher Gs may be related, probably, to the fact that the plants try to recover from injuries, since this treatment also caused the highest phytotoxicity grades to corn (Table 2). Reis et al. (2014), evaluating the effect of the herbicides oxadiazon, flumioxazin, oxyfluorfen and sulfentrazone (PROTOX inhibitors) applied pre-emergence of sunflower, did not observe changes in stomatal conductance (Gs), a behavior similar in part to the results of the present study.

Regarding the internal $\mathrm{CO}_{2}$ concentration ( $\mathrm{Ci}$ ), it was found that the lowest dose of saflufenacil applied alone was responsible for the lowest value of this variable (Table 3). For photosynthetic activity (A), a similar behavior was observed, with the lowest values obtained for the lowest doses of saflufenacil applied alone and mixed with glyphosate. These values are related to the low $\mathrm{Ci}$ caused by these treatments. Photosynthetic activity is directly affected by the internal $\mathrm{CO}_{2}$ concentration in leaf mesophile (Taiz et al., 2017). 
For water use efficiency (WUE), it was observed that the doses of 35 and $52.5 \mathrm{~g} \mathrm{ha}^{-1}$ of saflufenacil applied alone and in mixture with glyphosate, respectively, were the treatments that promoted the highest value for this variable. For carboxylation efficiency $(\mathrm{CE})$, there was wide variation between treatments. The inconsistency in the response of this variable can be attributed to the fact that $\mathrm{CE}$ is influenced by the relationship between photosynthesis and internal carbon concentration and, also, regulated by stomatal conductance (Machado et al., 2005; Machado et al., 2010). Leaf transpiration (E) showed great variation and the behavior of this variable was not directly influenced by the mixture of herbicides and variations in saflufenacil doses. The transpiration rates of Helianthus annus and Arachis hypogaea did not show any changes when subjected to the application of 250 and $500 \mathrm{~g} \mathrm{ha}^{-1}$ of sulfentrazone in the soil (Belo et al., 2016), similarly to the results found in this study.

Physiological assessments are punctual and highly dependent on environmental and soil conditions. Photosynthetic activity can change due to the application of chemicals, mainly herbicides, as some of them directly or indirectly affect the photosynthetic cycle (Concenço et al., 2014). PROTOX-inhibiting herbicides affect several vital physiological processes in plants. The formation of singlet oxygen promotes the peroxidation of cell membranes and, consequently, the death of plant tissue (Taiz et al. 2017).

Table 3. Effect of the herbicide saflufenacil applied in different doses alone or associated with glyphosate, evaluated at 35 days after the application of treatments, on stomatal conductance $\left(\mathrm{Gs}-\mathrm{mol} \mathrm{m}^{-1} \mathrm{~s}^{-1}\right)$, internal $\mathrm{CO}_{2}$ concentration $\left(\mathrm{Ci}-\mu \mathrm{mol} \mathrm{mol}^{-1}\right)$, photosynthetic activity ( $\mathrm{A}-\mu \mathrm{mol} \mathrm{mol}{ }^{-1}$ ), water use efficiency (WUE - mol $\mathrm{CO}_{2} \mathrm{~mol} \mathrm{H}_{2} \mathrm{O}^{-1}$ ), carboxylation efficiency $\left(\mathrm{CE}-\mathrm{mol} \mathrm{CO} \mathrm{m}^{-2} \mathrm{~s}^{-1}\right)$ and leaf transpiration $\left(\mathrm{E}-\mathrm{mol} \mathrm{H}_{2} \mathrm{O} \mathrm{m}^{-2} \mathrm{~s}^{-1}\right)$ of the SYN 488 VIP 3 corn hybrid. UFFS/Erechim/RS, 2018/19

\begin{tabular}{|c|c|c|c|c|c|c|c|}
\hline \multirow{2}{*}{\multicolumn{2}{|c|}{ Tretments }} & \multicolumn{6}{|c|}{ Physiological parameters of corn } \\
\hline & & Gs & $\mathrm{Ci}$ & $\mathrm{A}$ & EUA & $\mathrm{EC}$ & $\mathrm{E}$ \\
\hline \multicolumn{2}{|l|}{ T01- Weeded control } & $\begin{array}{c}0.117 \\
b^{1}\end{array}$ & $264.000 \mathrm{a}$ & $13.710 \mathrm{c}$ & $4.689 \mathrm{~b}$ & $0.052 \mathrm{~d}$ & $1.499 \mathrm{~b}$ \\
\hline \multicolumn{2}{|l|}{ T02- Glyphosate } & $0.100 \mathrm{~b}$ & $266.000 \mathrm{a}$ & $12.440 \mathrm{~d}$ & $4.064 \mathrm{~b}$ & $0.047 \mathrm{e}$ & $2.368 \mathrm{a}$ \\
\hline \multicolumn{2}{|l|}{ T03- Saflufenacil } & 109 & $203.875 \mathrm{c}$ & $09.726 \mathrm{e}$ & 6.7 & $0.047 \mathrm{e}$ & $1.216 \mathrm{~b}$ \\
\hline \multicolumn{2}{|l|}{ T04- Saflufenacil } & $122 \mathrm{~b}$ & $247.000 \mathrm{~b}$ & $15.405 \mathrm{~b}$ & $4.114 \mathrm{~b}$ & $0.062 \mathrm{c}$ & $1.833 \mathrm{~b}$ \\
\hline \multicolumn{2}{|l|}{ T05- Saflufenacil } & $0.116 \mathrm{~b}$ & $246.875 \mathrm{~b}$ & $18.331 \mathrm{a}$ & $4.745 \mathrm{~b}$ & $0.074 \mathrm{a}$ & $1.712 \mathrm{~b}$ \\
\hline \multicolumn{2}{|l|}{ T06- Saflufenacil } & $0.135 \mathrm{~b}$ & $256.125 \mathrm{~b}$ & $11.756 \mathrm{~d}$ & $4.605 \mathrm{~b}$ & $0.046 \mathrm{e}$ & $2.400 \mathrm{a}$ \\
\hline \multicolumn{2}{|l|}{ T07- Saflufenacil } & $0.126 \mathrm{~b}$ & $249.750 \mathrm{~b}$ & $14.190 \mathrm{c}$ & $5.121 \mathrm{~b}$ & $0.053 \mathrm{~d}$ & $2.361 \mathrm{a}$ \\
\hline \multicolumn{8}{|l|}{ glyphosate } \\
\hline \multicolumn{8}{|l|}{ T09- Saflufenacil } \\
\hline \multicolumn{2}{|l|}{$\begin{array}{l}\text { T10- S } \\
\text { glyphosate }\end{array}$} & $0.109 \mathrm{~b}$ & $240.250 \mathrm{~b}$ & $10.225 \mathrm{e}$ & $5.187 \mathrm{~b}$ & $0.045 \mathrm{e}$ & $1.342 \mathrm{~b}$ \\
\hline \multicolumn{2}{|c|}{ T11- Saflufenacil + glyphosate } & $0.125 \mathrm{~b}$ & $265.408 \mathrm{a}$ & $18.002 \mathrm{a}$ & $4.547 \mathrm{~b}$ & $0.068 \mathrm{~b}$ & $1.537 \mathrm{~b}$ \\
\hline \multicolumn{2}{|l|}{$\begin{array}{l}\text { T12- Sa } \\
\text { glyphosate }\end{array}$} & $0.237 \mathrm{a}$ & $277.957 \mathrm{a}$ & $18.277 \mathrm{a}$ & $5.249 \mathrm{~b}$ & $0.064 \mathrm{c}$ & $2.607 \mathrm{a}$ \\
\hline \multicolumn{2}{|l|}{ C.V. $(\%)$} & 32.37 & 5.01 & 5.23 & 18.96 & 2.80 & 16.96 \\
\hline
\end{tabular}

${ }^{1}$ Averages followed by equal letters in the column do not differ by the Scott-Knott test at $\mathrm{p} \leq 0,05$. 


\section{Macrothink

Several other studies have found reduced or low effects of herbicides on the studied physiological parameters. Alves et al. (2019), evaluating the effect of fomesafen and sulfentrazone, also PROTOX inhibitors, found little effect of these herbicides on the physiological parameters $\mathrm{Gs}, \mathrm{Ci}, \mathrm{A}, \mathrm{WUE}, \mathrm{CE}$ and $\mathrm{E}$ of various plant species grown in winter. Belo et al. (2016), testing the effect of doses of 250 and $500 \mathrm{~g} \mathrm{ha}^{-1}$ of sulfentrazone, did not observe changes in the Gs and EC of Canavalia ensiformis when compared with the control without application of the herbicide. Reis et al. (2014), in a test to evaluate the effect of PROTOX inhibiting herbicides applied pre-emergence, also did not observe changes in Gs, $\mathrm{Ci}, \mathrm{CO}_{2}$ consumption and WUE of sunflower plants, which corroborates the results of the present study.

Regarding the yield components of the crop, it was observed that the use of herbicides affected the evaluated parameters (Table 4). All treatments that received herbicides showed a higher ear length value (EL) when compared to the weeded control. The lowest values of number of grain rows per ear (NRE) were obtained for the application of glyphosate + saflufenacil mixtures, except when it was used in the lowest dose. The worst treatments for the number of grains per row (NGR) and number of grains per ear (NGE) were mixtures of glyphosate with saflufenacil at doses of 70 and $87.5 \mathrm{~g} \mathrm{ha}^{-1}$. For the mass of 1,000 grains (M1000G) only the application of saflufenacil alone at a dose of $70 \mathrm{~g} \mathrm{ha}^{-1}$ showed lower values than the weeded control.

Yield data show that doses of saflufenacil above $70 \mathrm{~g} \mathrm{ha}^{-1}$ cause losses on this variable (Table 4). The mixture of this herbicide with glyphosate can potentially decrease crop yield. In the associations between the two molecules, it was found that doses of saflufenacil above $87.5 \mathrm{~g}$ $\mathrm{ha}^{-1}$ decreased crop yield, on average, by approximately $57 \%$ when compared to the weeded control. 
Table 4. Ear length - EL (cm), number of rows per ear - NRE, number of grains per row NGR, number of grains per ear - NGE, mass of 1,000 grains - M1000G (g) and grain yield $\left(\mathrm{kg} \mathrm{ha}^{-1}\right.$ ) of the corn hybrid SYN 488 VIP 3, as a function of the application of doses of saflufenacil alone and mixed with glyphosate. UFFS/Erechim/RS, 2018/19

\begin{tabular}{lcccccc}
\hline Treatments & $\begin{array}{c}\text { EL } \\
(\mathrm{cm})\end{array}$ & NRE & NGR & NGE & $\begin{array}{c}\text { M1000G } \\
(\mathrm{g})\end{array}$ & $\begin{array}{c}\text { Yield } \\
\left(\mathrm{kg} \mathrm{ha}^{-1}\right)\end{array}$ \\
\hline T01- Weeded control & $15.16 \mathrm{e}$ & $16.13 \mathrm{~b}$ & $28.40 \mathrm{~d}$ & $479.32 \mathrm{~b}$ & $253.61 \mathrm{c}$ & $10044.34 \mathrm{a}$ \\
T02- Glyphosate & $15.89 \mathrm{~d}$ & $17.06 \mathrm{a}$ & $28.46 \mathrm{~d}$ & $481.62 \mathrm{~b}$ & $260.26 \mathrm{~b}$ & $9966.01 \mathrm{a}$ \\
T03- Saflufenacil & $16.11 \mathrm{~d}$ & $16.53 \mathrm{~b}$ & $29.30 \mathrm{c}$ & $505.30 \mathrm{a}$ & $269.48 \mathrm{~b}$ & $9937.50 \mathrm{a}$ \\
T04- Saflufenacil & $16.27 \mathrm{c}$ & $16.93 \mathrm{a}$ & $31.93 \mathrm{a}$ & $527.68 \mathrm{a}$ & $233.57 \mathrm{~d}$ & $10802.23 \mathrm{a}$ \\
T05- Saflufenacil & $15.83 \mathrm{~d}$ & $16.93 \mathrm{a}$ & $32.33 \mathrm{a}$ & $518.00 \mathrm{a}$ & $262.66 \mathrm{~b}$ & $9108.51 \mathrm{~b}$ \\
T06- Saflufenacil & $16.60 \mathrm{c}$ & $15.46 \mathrm{c}$ & $31.10 \mathrm{~b}$ & $483.96 \mathrm{~b}$ & $280.18 \mathrm{a}$ & $9178.06 \mathrm{~b}$ \\
T07- Saflufenacil & $16.38 \mathrm{c}$ & $16.40 \mathrm{~b}$ & $30.13 \mathrm{c}$ & $493.94 \mathrm{~b}$ & $268.46 \mathrm{~b}$ & $9086.38 \mathrm{~b}$ \\
T08- Saflufenacil + glyphosate & $16.31 \mathrm{c}$ & $16.67 \mathrm{a}$ & $29.80 \mathrm{c}$ & $508.02 \mathrm{a}$ & $263.58 \mathrm{~b}$ & $7309.55 \mathrm{~d}$ \\
T09- Saflufenacil +glyphosate & $16.85 \mathrm{~b}$ & $15.86 \mathrm{c}$ & $30.53 \mathrm{~b}$ & $496.43 \mathrm{~b}$ & $255.89 \mathrm{c}$ & $8297.18 \mathrm{c}$ \\
T10- Saflufenacil + glyphosate & $16.76 \mathrm{~b}$ & $15.40 \mathrm{c}$ & $24.40 \mathrm{f}$ & $412.96 \mathrm{c}$ & $259.18 \mathrm{~b}$ & $4142.43 \mathrm{e}$ \\
T11- Saflufenacil + glyphosate & $16.53 \mathrm{c}$ & $15.80 \mathrm{c}$ & $26.10 \mathrm{e}$ & $385.36 \mathrm{e}$ & $263.79 \mathrm{~b}$ & $4433.35 \mathrm{e}$ \\
T12- Saflufenacil + glyphosate & $17.32 \mathrm{a}$ & $14.13 \mathrm{~d}$ & $28.90 \mathrm{~d}$ & $416.36 \mathrm{c}$ & $251.68 \mathrm{c}$ & $4466.17 \mathrm{e}$ \\
\hline \multicolumn{1}{c}{ C.V. (\%) } & 2.02 & 2.29 & 2.92 & 3.37 & 2.61 & 6.83 \\
\hline
\end{tabular}

${ }^{1}$ Means followed by equal letters in the column do not differ by the Scott-Knott test at $\mathrm{p} \leq$ 0.05 .

Yield data (Table 4) corroborate the phytotoxicity information (Table 2). The mixtures of glyphosate + saflufenacil were the treatments that caused the highest levels of injuries and caused the main losses in grain yield. Moran et al. (2011), analyzing the selectivity of post-emergence saflufenacil applied on corn, observed that the crop's tolerance to the herbicide can be influenced by the plant's development stage, doses and the use of safeners. The same authors found that application at later stages increases the level of injuries; higher doses can cause severe symptoms of phytotoxicity; and that the use of safeners reduces the absorption of the herbicide and, consequently, the damage to the plant.

The results indicate that the application of saflufenacil alone in doses of up to $70 \mathrm{~g} \mathrm{ha}^{-1}$ has the potential to be used in corn. The possibility of using this herbicide after the corn emergence represents an important alternative to assist in the management of glyphosate-resistant and -tolerant eudicotyledons or even in the control of genetically modified soy (volunteer soybeans) that may come to infest the off-season corn crop. The application of glyphosate alone did not cause phytotoxicity or grain yield loss on the corn hybrid Syn 488 VIP 3. The application of herbicides interferes with physiological variables, especially when using glyphosate mixed with the highest doses of saflufenacil. The use of glyphosate + saflufenacil tank mixtures decreased grain yield in 43.96 and $40.81 \%$ when compared to the weeded control and the means of the applications carried out in isolation, respectively.

\section{Conclusions}

The use of the glyphosate + saflufenacil tank mixture causes severe phytoxicity symptoms and grain yield losses in the hybrid Syn 488 VIP 3. 
The corn hybrid Syn 488 VIP 3 supports the application of saflufenacil when used alone, in a dose of up to $70 \mathrm{~g} \mathrm{ha}^{-1}$, with low phytotoxicity symptoms and no reduction in grain yield.

\section{Acknowledgements}

The author thanks the National Council for Scientific and Technological Development (CNPq), Federal University of Fronteira Sul (UFFS) for financial support and Foundation for Research of the State of Rio Grande do Sul (FAPERGS) for fellowships.

\section{References}

Alves, C. et al. (2019). Physiological characteristics of hibernal plants with phytomediator potential under the influence of the herbicides fomesafen and sulfentrazone. Revista de Ciências Agroveterinárias, 18, 1-12. https://doi.org/10.5965/223811711812019001

Ashigh, J. J., Hall, C. (2010). Bases for interactions between saflufenacil and glyphosate in plants. Journal of Agricultural and Food Chemistry, 58, 7335-7343. https://doi.org/10.1021/jf100595a

Basso, F. J. M. et al. (2016). Weed management in RR maize ${ }^{\circledR}$ with herbicides applied alone or associated with glyphosate. Revista de Ciências Agroveterinárias, 17, 148-157. https://doi.org/10.5965/223811711722018148

Belo, A. F. et al. (2016). Photosynthetic activity of plants grown in soil contaminated with sulfentrazone. Revista Brasileira de Herbicidas, 15, 165-174. https://doi.org/10.7824/rbh.v15i2.456

CONAB. (2020). Monitoring the Brazilian harvest. http://www.conab.gov.br/arquivos/18_01_11_14_17_49_graos_4o_levantamento.pdf.

Concenço, G. et al. (2014). Physiological characteristics of Crambe abyssinica under herbicide application. Revista de Ciências Agrárias, 37, 361-369. http://www.scielo.mec.pt/scielo.php?script=sci_arttext\&pid=S0871-018X2014000300014

Contini, E. et al. (2019). Corn - Characterization and Technological Challenges. Series challenges of Brazilian agribusiness (NT2). EMBRAPA, p.1-45.

Costa, L. L. et al. (2015). Interaction between herbicides in the control of voluntary RR soybean in corn crop. Revista Brasileira de Herbicidas, 18, 655. https://doi.org/10.7824/rbh.v18i2.655

Dalazen, G. et al. (2015). Synergism in the combination of glyphosate and saflufenacil for buva control. Pesquisa Agropecuária Brasileira, 45, 249-256. https://doi.org/10.1590/1983-40632015v4533708

EMBRAPA (2013). Brazilian system of soil classification. Sistema brasileiro de classificação de solos. 1st ed. Brasília: Embrapa Solos. p. 154 p

Ferreira, D. F. (2011). Sisvar: a computer statistical analysis system. Ciência e Tecnologia, 35, 1039-1042. https://doi.org/10.1590/S1413-70542011000600001 
Galon, L. et al. (2018). Chemical management of weeds in corn hybrids. Weed Biology and Management, 18, 26-40. https://doi.org/10.1111/wbm.12141

Grossmann, K. et al. (2010). The herbicide saflufenacil (Kixor ${ }^{\mathrm{TM}}$ ) is a new inhibitor of protoporphyrinogen IX oxidase activity. Weed Science, 58, 1-9. https://doi.org/10.1614/WS-D-09-00004.1

Lourencetti, C. et al. (2005). Evaluation of the potential for groundwater contamination by pesticides: comparison between leaching forecasting methods. Pesticidas: Revista Ecotoxicologia e Meio Ambiente, 15, 1-14.

Lucio, F. R. et al. (2019). Dispersal and frequency of glyphosate-resistant and glyphosate-tolerant weeds in soybean-production edaphoclimatic microregions in Brazil. Weed Technology, 33, 217-231. https://doi.org/10.1017/wet.2018.97

Machado, A. F. L. et al. (2010). Photosynthetic efficiency and water use in eucalyptus plants sprayed with glyphosate. Planta Daninha, 28, 319-327. https://doi.org/10.1590/S0100-83582010000200011

Machado, E. C. et al. (2005). Photosynthetic responses of three citrus species to environmental factors. Pesquisa Agropecuária Brasileira, 40, 1161-1170. https://doi.org/10.1590/S0100-204X2005001200002

MAPA/AGROFIT. (2020). Plant health agrotsystems - Open Consultation. http://agrofit.agricultura.gov.br/agrofit_cons/principal_agrofit_cons.

Moran, M. et al. (2011). Sodium safens saflufenacil applied postemergence to corn (Zea mays). Weed science, 59, 4-13. https://doi.org/10.1614/WS-D-10-00051.1

Petter, F. A. et al. (2015). Volunteer $\mathrm{RR}^{\circledR}$ corn management in Roundup Ready ${ }^{\circledR}$ soybean-corn succession system. Planta Daninha, 33, 119-128. https://doi.org/10.1590/S0100-83582015000100014

Piasecki, C. et al. (2017). Technical effectiveness and economic return of the glyphosate-resistant hairy fleabane management in soybean pre-emergence. Revista Brasileira de Herbicidas, 16, 20-29. https://doi.org/10.7824/rbh.v16i1.510

Reis, R. M. et al. (2014). Physiological aspects and sunflower growth after herbicide application in pre-emergence. Revista Agro@mbiente On-line, 8, 352-358. https://doi.org/10.5327/Z1982-8470201400032171

Rodrigues, B. N., \& Almeida, F. R. (2018). Herbicide Guide. (7th ed.). Londrina: Authors' Edition. p. 764

ROLAS (2016). Fertilization and liming manual for the states of Rio Grande do Sul and Santa Catarina. Manual de adubação e calagem para os estados do Rio Grande do Sul e Santa Catarina. 10th ed. Porto Alegre: Sociedade Brasileira de Ciência do Solo. p. 376

SBCPD (1995). Procedures for installation, evaluation and analysis of experiments with herbicides. Londrina: SBCPD. p. 42 


\section{Macrothink}

Journal of Agricultural Studies

ISSN 2166-0379 2020, Vol. 8, No. 3

Silva, A. F. M. et al. (2017). Selectivity of herbicides isolated and in associations for RR2/LL corn. Revista Brasileira de Herbicidas, 16, 60-66. https://doi.org/10.7824/rbh.v16i1.509

Taiz, L. et al. (2014). Plant Physiology and Development. 6th ed. Sunderland: Sinauer Associates. p. 896

Timossi, P. C., \& Freitas, T. T. (2011). Efficacy of nicosulfuron alone and associated with atrazine in weed management in corn. Revista Brasileira de Herbicidas, 10, 210-218. https://doi.org/10.7824/rbh.v10i3.123

\section{Copyright Disclaimer}

Copyright for this article is retained by the author(s), with first publication rights granted to the journal.

This is an open-access article distributed under the terms and conditions of the Creative Commons Attribution license (http://creativecommons.org/licenses/by/4.0/). 